\title{
Effect of thickener agents on dental enamel microhardness submitted to at-home bleaching
}

\author{
Efeito de agentes espessantes na microdureza \\ do esmalte submetido ao clareamento \\ dental caseiro
}

\section{José Augusto Rodrigues ${ }^{(a)}$ Glauco Paulo Felício Oliveira(b) Cristiane Mariote Amaral ${ }^{(a)}$}

(a) PhDs, Assistant Professors, Dental Research and Graduate Studies Division, Department of Restorative Dentistry; (b) Undergraduate Dentistry Student - Guarulhos University, Guarulhos.

\author{
Corresponding author: \\ José Augusto Rodrigues \\ Universidade de Guarulhos \\ CEPPE - Centro de Pós Graduação, \\ Pesquisa e Extensão \\ Pça. Tereza Cristina, 58 \\ Centro - Guarulhos - SP - Brazil \\ CEP: 07023-070 \\ E-mail: jrodrigues@prof.ung.br
}

\begin{abstract}
Dental bleaching occurs due to an oxidation reaction between the bleaching agents and the macromolecules of pigments in the teeth. This reaction is unspecific and the peroxides can also affect the dental matrix causing mineral loss. On the other hand, recent studies have suggested that the thickener agent carbopol can also cause mineral loss. Thus, the objective of this study was to evaluate in vitro the effect of at-home dental bleaching on dental enamel microhardness after the use of bleaching agents with and without carbopol as a thickener agent. Bovine dental slabs with $3 \times 3 \times 3 \mathrm{~mm}$ were obtained, sequentially polished, and randomly divided into 4 groups according to the experimental treatment: G1: 2\% carbopol; G2: 10\% carbamide peroxide with carbopol; G3: carbowax; G4: 10\% carbamide peroxide with poloxamer. Bleaching was performed daily for 4 weeks, immersed in artificial saliva. Enamel microhardness values were obtained before the treatment $\left(\mathrm{T}_{0}\right)$ and $7\left(\mathrm{~T}_{1}\right), 14\left(\mathrm{~T}_{2}\right), 21\left(\mathrm{~T}_{3}\right), 28\left(\mathrm{~T}_{4}\right)$, and $42\left(\mathrm{~T}_{5}\right)$ days after the beginning of the treatment. ANOVA and Tukey's test revealed statistically significant differences only for the factor Time $(\mathrm{F}=5.48 ; \mathrm{p}<0.01)$. All bleaching and thickener agents caused no alterations on the enamel microhardness.
\end{abstract}

Descriptors: Dental enamel; Hardness tests; Tooth bleaching; Thickeners/adverse effects.

Resumo: O clareamento dental ocorre devido a uma reação de oxidação entre o agente clareador e as macromoléculas de pigmentos presentes nos dentes. Esta reação é inespecífica e o peróxido pode agir na matriz dental causando perdas de mineral. Por outro lado, estudos recentes sugerem que o agente espessante carbopol também pode causar perda mineral. Assim, o objetivo deste trabalho foi avaliar in vitro o efeito do clareamento caseiro sobre a microdureza do esmalte após o uso de agentes clareadores com e sem carbopol como espessante. Fragmentos de esmalte bovino de $3 \times 3 \times 3 \mathrm{~mm}$ foram obtidos, polidos seqüencialmente e aleatoriamente divididos em 4 grupos de acordo com o tratamento experimental: G1: carbopol a 2\%; G2: peróxido de carbamida a $10 \%$ com carbopol; G3: carbowax; G4: peróxido de carbamida a $10 \%$ com poloxamer. O clareamento foi realizado diariamente por 4 semanas em saliva artificial. A microdureza do esmalte foi avaliada antes $\left(\mathrm{T}_{0}\right)$ e após $7\left(\mathrm{~T}_{1}\right), 14\left(\mathrm{~T}_{2}\right), 21\left(\mathrm{~T}_{3}\right), 28\left(\mathrm{~T}_{4}\right)$, e $42\left(\mathrm{~T}_{5}\right)$ dias do início do tratamento. A ANOVA e o teste de Tukey revelaram diferenças estatísticas significantes somente para o fator Tempo $(\mathrm{F}=5,48 ; \mathrm{p}<0,01)$. Os agentes clareadores e espessantes não causaram alterações na microdureza do esmalte.

Descritores: Esmalte dentário; Testes de dureza; Clareamento de dente; Espessantes/efeitos adversos. 


\section{Introduction}

Discolored teeth are considered a major problem by society and they are incorrectly attributed to diseases. ${ }^{8}$ As a solution for this kind of problem there are many options like crowns, laminated veneers, enamel microabrasion, and dental bleaching. ${ }^{8}$ Among these techniques, dental bleaching is the most conservative, easy, and commonly used by clinicians. ${ }^{8}$

At-home bleaching has become one of the most used techniques because of its simplicity, low cost and safety due to the use of low concentrations of peroxide ( $10 \%$ to $16 \%$ carbamide peroxide). ${ }^{8} \mathrm{Al}$ though $10 \%$ carbamide peroxide is still currently commonly used, manufacturers have recently begun to introduce higher concentrations of bleaching agents and alternative methods for tooth bleaching to achieve faster results. ${ }^{8,11}$

Teeth are bleached by an oxidation-reduction reaction caused by the decomposition of the hydrogen peroxide into free radicals such as oxygen and perhydroxyl..$^{8,13}$ Because of the absence of an electron on the last layer, the oxygen $\left(\mathrm{O}^{*}\right)$ and perhydroxyl $\left(\mathrm{HO}_{2}{ }^{\circ}\right)$ - free radicals - are extremely electrophilic and diffuse throughout enamel and dentin matrix to attack the macromolecules of pigments (organic molecules) and acquire stability. ${ }^{7,8}$ Then, the intrinsic pigments composed by highly unsaturated organic macromolecules are transformed into less complex molecules, which are smaller, simpler and lighter than the original ones. ${ }^{8}$

However, this reaction is unspecific, and the organic and inorganic matrix of the enamel and dentin might be affected by the bleaching agents, and undesirable effects such as topography alterations and mineral loss may occur. $3,5,9,13,14,16,18,19,22,23$

On the other hand, recent studies suggest that such alterations are not only related to the peroxide application. ${ }^{3,19}$ Few researches have observed in in vitro or in situ studies that treatment with carbopol (the most used thickener agent) may cause a decrease of enamel microhardness. ${ }^{3,14,19}$ However, there is no conclusive data about the effects of carbopol. The action of carbopol should be better investigated because it may be synergistically acting with free radicals and may further increase the mineral loss produced by the use of other agents.
The aim of this study was to evaluate the effect of an in vitro treatment with $10 \%$ carbamide peroxide bleaching agents with and without carbopol, and the effect of the treatment with $2 \%$ carbopol on dental enamel microhardness.

\section{Material and Methods Preparation of the dental slabs}

After extraction, 40 bovine teeth were stored in a $0.1 \%$ thymol solution. They were submitted to a soft-tissue debridement and the crowns were sectioned to obtain 72 dental slabs with $3 \times 3 \times 3 \mathrm{~mm}$ using double-faced diamond discs (KG Sorensen, Barueri, SP, Brazil). The dental slabs were individually embedded in autopolimerizing polystyrene resin (Cromex, São Paulo, SP, Brazil) in a PVC ring mold, allowing only one side of the dental slab to be left unsealed. The enamel surface of the slabs was serially polished by 400,600 , and 1,000 grit $\mathrm{Al}_{2} \mathrm{O}_{3}$ abrasive paper (Carborundum Abrasivos, Recife, PE, Brazil) with water as a cooler to obtain flat, standardized enamel surfaces. Subsequently, they were polished with diamond pastes of 6,3 , and $1 \mu \mathrm{m}$ and polishing cloths with a mineral oil lubricant (Arotec Ind. Com. Ltda., Cotia, SP, Brazil). After that, the specimens were maintained in deionized distilled water until the microhardness test was performed.

\section{Microhardness tests}

Microhardness measurements were performed in the center of the specimen prior to the experimental treatment to be used as control $\left(\mathrm{T}_{0}\right)$, and at 7 , 14,21 , and 28 days of exposure to the bleaching agents $\left(\mathrm{T}_{1}, \mathrm{~T}_{2}, \mathrm{~T}_{3}\right.$, and $\left.\mathrm{T}_{4}\right)$. Another microhardness evaluation at 42 days $\left(T_{5}\right)$ was performed to evaluate the post-bleaching period. Knoop microhardness was measured keeping the long axis of the diamond parallel to the outer enamel surface using a microhardness tester (Microdurômetro Digital 10A 1000 HVS-1000A, Panambra Ind. e Tec. S.A., São Paulo, SP, Brazil). At each one of the test times, 5 indentations were made on each specimen applying a $25 \mathrm{~g}$ load for $5 \mathrm{~s}$. The indentations were done on pre-established sites. $\mathrm{T}_{0}$ indentations were located on the center of the slab. The indentations of the other times were located at $300 \mu \mathrm{m}$ around those of $\mathrm{T}_{0}$. 


\section{Experimental treatment}

For the experimental treatments, the specimens were randomized into four groups $(\mathrm{n}=18)$ as presented in Table 1.

The in vitro at-home bleaching was performed as described by Rodrigues et al. ${ }^{18}$ (2001), and used by Basting et al. ${ }^{3}$ in 2003, and Basting et al. ${ }^{2}$ in 2005. The respective treatment agent was applied for 6 hours a day covering the dental slabs with $0.2 \mathrm{ml}$ of the material. The specimens were placed in vacuumformed custom trays and immersed in a closed plastic container with artificial saliva at $37^{\circ} \mathrm{C}$.

After the bleaching period, the treatment agent was removed under running deionized and distilled water. For the remaining time of the day, the specimens were individually kept in $11 \mathrm{ml}$ of artificial saliva that was daily changed. The artificial saliva was used as Featherstone et al. ${ }^{6}$ (1986) proposed, according to what

Table 1 - Experimental groups, bleaching agents and composition.

\begin{tabular}{c|l|l}
\hline Groups & \multicolumn{1}{|c|}{ Bleaching agent } & \multicolumn{1}{c}{ Composition } \\
\hline$G 1$ & - & 2\% Carbopol \\
\hline$G 2$ & $\begin{array}{l}\text { 10\% carbamide } \\
\text { peroxide (Whiteness } \\
\text { Perfect) }\end{array}$ & $\begin{array}{l}\text { Neutralized carbopol, potassium } \\
\text { nitratum, sodium fluoride, } \\
\text { glycol, and deionized water. }\end{array}$ \\
\hline G3 & - & Carbowax \\
\hline G4 & $\begin{array}{l}\text { 10\% carbamide } \\
\text { peroxide (Colgate } \\
\text { Platinum Overnight) }\end{array}$ & $\begin{array}{l}\text { Calcium pyrophosphate, water, } \\
\text { poloxamer 407, PEG 12, } \\
\text { glycerin, dicalcium phosphate } \\
\text { dihydrate, polyethylene oxide, } \\
\text { sodium acid pyrophosphate, } \\
\text { flavor, sodium lauryl sulfate, } \\
\text { sodium saccharin, and disodium } \\
\text { dihydrate EDTA. }\end{array}$ \\
\hline
\end{tabular}

Serra, Cury ${ }^{20}$ (1992) described, containing $50 \mathrm{mmol} / \mathrm{l}$ $\mathrm{KCl}, 1.5 \mathrm{mmol} / \mathrm{l} \mathrm{Ca}, 0.9 \mathrm{mmol} / \mathrm{l} \mathrm{PO}_{4}, 20 \mathrm{mmol} / \mathrm{l}$ trihydroxymethyl-aminomethane buffer at $\mathrm{pH}$ 7.0. After 28 days of the experimental treatments, the specimens were stored in artificial saliva for additional 14 days.

\section{Statistical analysis}

The measurements of the indentations, in micrometers, taken from each specimen at each time were used to obtain the Knoop hardness number $(\mathrm{KHN})$ by the following calculation: $\mathrm{KHN}=\left(14.23 \times 10^{3} \times \mathrm{F}\right) /$ $\mathrm{d}^{2}$, where $\mathrm{F}$ is the applied load value $(\mathrm{g})$ and $\mathrm{d}$ is the diagonal indentation $(\mu \mathrm{m})$.

The means of the 5 Knoop hardness (KHN) measurements from each specimen, made initially and following treatment, were statistically analyzed. Data were subjected to split plot analysis of variance, which showed statistically significant differences, followed by Tukey's test $(\alpha=0.05)$.

\section{Results}

The mean values of enamel microhardness, before and following the treatments, and the respective standard deviations are shown in Table 2, and the behavior of enamel microhardness may be observed in Graph 1. The ANOVA and Tukey's tests revealed no statistically significant differences regarding the factor experimental treatment $(\mathrm{F}=0.37 ; \mathrm{p}=0.78)$. Statistically significant differences were found for the factor time $(\mathrm{F}=5.48 ; \mathrm{p}<0.01)$, therefore all groups had the same behavior over time. There was no statistical significant differences for the interaction between the factors experimental treatment and time $(\mathrm{F}=1.35 ; \mathrm{p}=0.16)$.

Table 2 - Mean values of initial and final Knoop microhardness measurements (KHN), and standard deviations (sd) for each group at each time.

\begin{tabular}{|c|c|c|c|c|c|c|c|c|c|c|c|c|}
\hline \multirow{2}{*}{ Groups } & \multicolumn{12}{|c|}{ Time } \\
\hline & Initial & sd & 7 & $\mathrm{sd}$ & 14 & $\mathrm{sd}$ & 21 & sd & 28 & $\mathrm{sd}$ & 42 & sd \\
\hline Carbopol & 369.2 & 56.1 & 349.2 & 59.1 & 344.3 & 39.7 & 351.7 & 26.6 & 340.0 & 34.3 & 354.4 & 34.9 \\
\hline Whiteness & 334.5 & 64.2 & 369.6 & 40.8 & 343.7 & 56.1 & 345.3 & 43.4 & 341.3 & 28.8 & 348.9 & 24.3 \\
\hline Carbowax & 348.4 & 45.0 & 376.7 & 60.6 & 362.6 & 69.2 & 334.8 & 30.5 & 334.3 & 35.2 & 356.6 & 37.8 \\
\hline Colgate Platinum & 350.1 & 44.9 & 371.8 & 53.4 & 333.2 & 37.0 & 334.7 & 55.3 & 322.8 & 20.3 & 351.1 & 21.3 \\
\hline Means & 353.1 & $A B$ & 366.2 & A & 345.9 & B & 341.6 & B & 334.6 & B & 352.8 & $A B$ \\
\hline
\end{tabular}

Same letters indicate mean values that are not statistically different for the factor Time. 


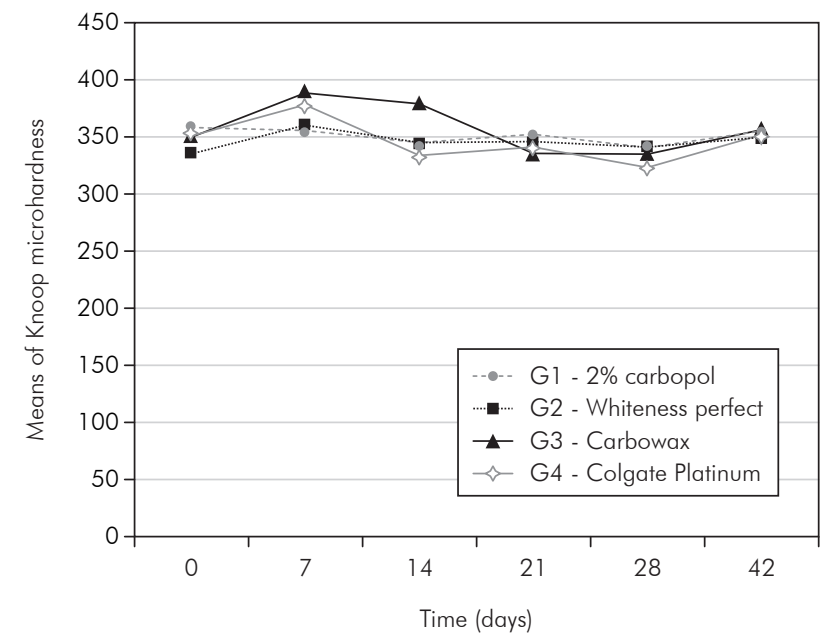

Graph 1 - Means of Knoop microhardness values for each group over time.

The Tukey test showed statistical differences among the studied times. Although at $\mathrm{T}_{1}$ all groups did not differ statistically from $\mathrm{T}_{0}$, there was a numerical increase in mean microhardness, except for G1.

From $T_{1}$ to $T_{2}, T_{3}$, and $T_{4}$, the mean values of microhardness decreased and statistically differed from that at $\mathrm{T}_{1}$. However, the data obtained at $\mathrm{T}_{2}$, $\mathrm{T}_{3}$, and $\mathrm{T}_{4}$ were statistically similar to that at $\mathrm{T}_{0}$.

From $\mathrm{T}_{4}$ to $\mathrm{T}_{5}$, all groups showed a non statistical increase in the means of microhardness. The data obtained at $\mathrm{T}_{5}$ did not differ from that obtained at the other times.

\section{Discussion}

The effects of bleaching agents and their compounds on teeth have been widely discussed by researchers. ${ }^{2,12-14,19}$ Bleaching agents can permeate the tooth structure and break the molecules of stain. ${ }^{8}$ However, this reaction is not specific and the matrix of enamel and dentin may be affected.

Several studies have demonstrated surface alterations in the enamel exposed to carbamide peroxide bleaching agents like pittings, ${ }^{10,21}$ erosions, ${ }^{15,21}$ porosities, ${ }^{10,15}$ waviness, ${ }^{15,21}$ surface roughness increase, ${ }^{15,25}$ and dissolutions ${ }^{1}$ similar to those of initial caries. ${ }^{17}$ These effects are directly related to the time of exposure and concentration of the active agent. ${ }^{11}$ The longer the exposure and higher the concentration, the greater the effect of the oxidation process, the color change ${ }^{8}$ and also the side effects. ${ }^{11}$

The experimental design employed in this study consisted in the exposure for 28 days of the enamel slabs to the bleaching or thickener agents for 6 hours a day, similarly to clinical night use, followed by immersion in an artificial saliva solution for 18 hours. Immersion in the artificial saliva solution, which contains calcium and phosphate, might promote a remineralization effect similar to that produced in human saliva, which is very important to make the results closer to those obtained in clinical conditions.

A not statistically significant increase in enamel microhardness was found from $T_{0}$ to $T_{1}$. This phenomenon was not expected. It may, however, have happened because of the immersion of the specimens in the deionized distilled water, which causes some demineralization effect, before the beginning of the treatment. Thus, in the first week, the use of artificial saliva may have had promoted remineralization of the specimens.

Despite the use of artificial saliva, the experimental groups of this study suffered microhardness loss from $T_{1}$ to $T_{2}, T_{3}$, and $T_{4}$, showing that the artificial saliva solution was not able to totally revert the detrimental effects caused by the continuous use of the bleaching agents, and some enamel demineralization may be expected. This finding did not agree with those of several authors that showed no alterations on enamel after exposure to bleaching. . $4,9,12,14,21,22$ However, most of them are unanimous in noticing the occurrence of enamel alterations by SEM. 5,9,12,21,23

On the other hand, Basting et al. ${ }^{3}$, in 2003, showed that an artificial saliva solution cannot reestablish the initial enamel hardness during the use of bleaching agents for longer periods, but after the end of the treatment the remineralization potential of this solution can reestablish enamel microhardness. Such effect was also observed in the present study at $\mathrm{T}_{5}$ (post bleaching period) and may also be expected in clinical conditions of less intense demineralization because of the presence of natural saliva and fluoride exposure. 
Demineralization is also related to the viscosities of the bleaching agents. ${ }^{2,13,19,22}$ Thickener agents like carbopol cause detrimental effects on enamel over the treatment time. ${ }^{2,13,19,22}$ In this study, the application of $2 \%$ carbopol or carbowax caused no effect on enamel microhardness that could not be fixed by the remineralizing potential of the artificial saliva. This result is not in agreement with those of previous studies, which have observed a statistical significant reduction in enamel microhardness ${ }^{2,19}$ after treatment with the thickener agent (carbopol). McCraken, Haywood ${ }^{14}$ (1995) showed lower values of enamel microhardness after the use of $10 \%$ carbamide peroxide and carbopol when compared to the use of $10 \%$ carbamide peroxide without a thickener agent. ${ }^{14}$

Basting et al. ${ }^{3}$ (2003) showed a loss in dental enamel microhardness after the in vitro treatment with the thickener agent carbopol. Rodrigues et al. ${ }^{19}$ (2005) have demonstrated a reduction in human dental enamel microhardness after in situ treatment with carbopol for 3 weeks. Furthermore, a research conducted by Basting et al. ${ }^{2}$ (2005) aimed to compare the microhardness of enamel after a treatment with $10 \%$ carbamide peroxide, carbopol, and glycerin, and it revealed that the association of those agents produced a decrease in sound enamel microhardness. However, these authors used carbopol for 8 hours per day with 16 hours in artificial saliva or in natural saliva. Thus, the detrimental effect they found may be related to the exposure time, which in the present study was of 6 hours followed by 18 hours in artificial saliva per day.

Carbopol is an exceptional thickener, suspending agent and stabilizer, utilized in a wide variety of personal care products at concentrations lower than $1 \%$. Carbopol was added to the bleaching agents to change the carbamide peroxide formulation, that was liquid, into a gel to avoid a greater loss of the bleaching material from the tray, ${ }^{1}$ to prolong the

\section{References}

1. Akal N, Over H, Olmez A, Bodur H. Effects of carbamide peroxide containing bleaching agents on the morphology release of hydrogen peroxide from the carbamide peroxide and to enhance the contact between the peroxide and the tooth. It also triples or quadruples the active release time of peroxide. However, it is an acidic polymer that may cause demineralization, and it has a high calcium-binding capacity that can inhibit hydroxyapatite crystal growth. ${ }^{24}$

The carbowax applied in G3 is a polymer of ethylene oxide and water and their ethers (polyethylene glycol), and it is very used as a surfactant in industry, including foods, cosmetics and pharmaceutics. It was used here as an alternative thickener agent based on the formulation of the bleaching agent of G4, whose thickener agent is poloxamer, a co-polymer of polyethylene glycol used as an emulsifying, surfactant, and wetting agent similar to carbowax.

Manufacturers have made no claims about the action of the thickener agents, so these agents have generally been considered inactive ingredients. They could, however, act as demineralizing agents ${ }^{14}$ or as an impermeable barrier, inhibiting the penetration of the artificial saliva solution through the enamel surface and avoiding the restoration of normal microhardness values. ${ }^{3}$

This study showed that the in vitro use of carbopol or carbowax caused no mineral loss, but further studies should be conducted to assess the effect of thickener agents for longer exposure times and also to study other options of thickener agents that may cause less effects on enamel.

\section{Conclusions}

Under the experimental conditions of this study, it can be concluded that at-home dental bleaching with $10 \%$ carbamide peroxide and the treatment with $2 \%$ carbopol or carbowax for 6 hours daily did not statistically reduce enamel microhardness. If some microhardness loss occured it could be reverted by the action of artificial saliva in a post-bleaching period. and subsurface hardness of enamel. J Clin Pediatr Dent. 2001;25(4):293-6. 
2. Basting RT, Rodrigues AL Jr, Serra MC. The effect of $10 \%$ carbamide peroxide, carbopol, and/or glycerin on enamel and dentin microhardness. Oper Dent. 2005;30(5):608-16.

3. Basting RT, Rodrigues AL Jr, Serra MC. The effects of seven carbamide peroxide bleaching agents on enamel microhardness over time. J Am Dent Assoc. 2003;134(10):1335-42.

4. Basting RT, Rodrigues Junior AL, Serra MC. The Effect of $10 \%$ carbamide peroxide bleaching material on microhardness of sound and demineralized enamel and dentin in situ. Oper Dent. 2001;26(6):531-9.

5. Bitter NC. A scanning electron microscopy study of the effect of bleaching agents on enamel: a preliminary report. J Prosthet Dent. 1992;67(6):852-5.

6. Featherstone JDB, O’Reilly MM, Shariat M. Enhancement of remineralization in vitro and in vivo. In: Leach AS. Factors relating to demineralization and remineralization of teeth. Oxford: IRL Press; 1986. p. 23-4.

7. Frysh H, Bowles WH, Baker F, Rivere-Hidalgo F, Guillen G. Effect of $\mathrm{pH}$ on hydrogen peroxide bleaching agents. J Esthet Dent. 1995;7(3):130-3.

8. Goldstein RE, Garber DA. Complete dental bleaching. Chicago: Quintessence Books; 1995. 165 p.

9. Hegedüs C, Bistley T, Flóra-Nagy E, Keszthelyi G, Jenei A. An atomic force microscopy study on the effect of bleaching agents on enamel surface. J Dent. 1999;27(7):509-15.

10. Leonard RH, Bentley CD, Haywood VB. Salivary pH changes during $10 \%$ carbamide peroxide bleaching. Quintessence Int. 1994;25(8):547-50.

11. Leonard RH, Sharma A, Haywood VB. Use of different concentrations of carbamide peroxide for bleaching teeth: an in vitro study. Quintessence Int. 1998;29(8):503-7.

12. Lopes GC, Bonissoni L, Baratieri LN, Vieira LCC, Monteiro S Jr. Effect of bleaching agents on the hardness and morphology of enamel. J Esthet Restor Dent. 2002;14(1):24-30.

13. McCracken MS, Haywood VB. Demineralization effects of 10 percent carbamide peroxide. J Dent. 1996;24(6):395-8.

14. McCracken MS, Haywood VB. Effects of $10 \%$ carbamide peroxide on the subsurface hardness of enamel. Quintessence Int. $1995 ; 26(1): 21-4$.
15. McGuckin RS, Babin JF, Meyer BJ. Alterations in human enamel surface morphology following vital bleaching. J Prosthet Dent. 1992;68(5):754-60.

16. Oltu Ü, Gürgan S. Effects of three concentrations of carbamide peroxide on the structure of enamel. J Oral Rehabil. 2000;27(4):332-40

17. Potocnik I, Kosec L, Gaspersic D. Effect of $10 \%$ carbamide peroxide bleaching gel on enamel microhardness, microstructure, and mineral content. J Endod. 2000;26(4):203-6.

18. Rodrigues JA, Basting RT, Serra MC, Rodrigues Junior AL. Effects of $10 \%$ carbamide peroxide bleaching on enamel microhardness at different bleaching times. Am J Dent. 2001;14(2):67-71.

19. Rodrigues JA, Marchi GM, Ambrosano GMB, Heymann HO, Pimenta LAF. Microhardness evaluation of in situ vital bleaching on human dental enamel using a novel study design. Dent Mater. 2005;21(11):1059-67.

20. Serra MC, Cury JA. The in vitro effect of glass-ionomer cement restoration on enamel subjected to a demineralization and remineralization model. Quintessence Int. 1992;23(2):1437.

21. Shannon H, Spencer P, Gross K, Tira D. Characterization of enamel exposed to $10 \%$ carbamide peroxide bleaching agents. Quintessence Int. 1993;24(1):39-44.

22. Smidt A, Weller D, Roman I, Gedalia I. Effect of bleaching agents on microhardness and surface morphology of tooth enamel. Am J Dent. 1998;11(2):83-5.

23. Tong LS, Pang MK, Mok NV, King NM, Wei SH. The effects of etching, micro-abrasion, and bleaching on surface enamel. J Dent Res. 1993;72(1):67-71.

24. van der Reijden WA, Buijs MJ, Damen JJ, Veerman EC, ten Cate JM, Nieuw Amerongen AV. Influence of polymers for use in saliva substitutes on de- and remineralization of enamel in vitro. Caries Res. 1997;31(3):216-23.

25. Wandera A, Feigal RJ, Douglas WH, Pintado MR. Homeuse tooth bleaching agents: an in vitro study on quantitative effects on enamel, dentin and cementum. Quintessence Int. 1994;25(8):541-6. 